\title{
2009 TMS President Ray Peterson: Everyone Wins When Members Say "Yes" to Society Involvement
}

\section{Ray Peterson}

It is with great excitement and honor that I accept the presidency of The Min-

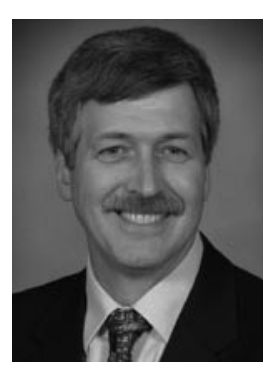
erals, Metals and Materials Society for 2009-2010. Let me introduce myself. My name is Ray Peterson. I am married to my spouse Lallie, who is a metallurgical engineer also, and have two teenaged children, Kyle and Cristen. I have worked in the aluminum industry for the past 25 years; first for Reynolds Metals at the Manufacturing and Technology Laboratory and later for IMCO Recycling. IMCO later morphed into Aleris International as the result of a series of mergers and acquisitions. My professional career has focused on process research and development.

I have been an active member of TMS since 1985. As a student member I wasn't too sure what TMS did, but I enjoyed the meetings and appreciated the research papers given. As a young professional, I sought access to both the technical knowledge being presented and the opportunity to make contacts in industry, academia, and at other research organizations. This access assisted in my career development. As I progressed in my career, TMS benefited me in other ways. I sharpened my skills in giving oral and written presentations. I broadened my exposure to other areas of material science and metallurgy. I gained leadership techniques (sometimes from both good and bad examples), and I learned to manage complex projects and deal with "interesting" personalities as a symposium organizer or a committee leader. I have served as chair of two different technical committees, served on several ad- ministrative committees, been involved with a number of symposia organizing committees, edited two books, and was chair of the Light Metals Division. I have even been lucky enough to have been honored several times with awards from TMS. Throughout this period, I have met remarkable individuals from all areas of metallurgy and material science. TMS has been an extremely positive influence on my career and on my life in general.

My goal as president is to help others benefit from TMS in the future as much as I have benefited in the past. We can best accomplish this by keeping TMS strong and vibrant through a continuation of the initiatives that our Board of Directors has started. Our Strategic Plan is well laid out and strong. The more recent initiatives discussed by our outgoing President, Diran Apelian, fit within these broad precepts.

I feel that we can improve the performance of TMS in three areas:

- Greater involvement of our parttime members is critical. We must find ways of lowering the barriers to greater participation by the many meeting attendees who are only involved with TMS once a year. More of our members should be encouraged to participate in the initial stages of society involvement so they can benefit from the interactions. This would include presenting papers, acting as a session chair at a meeting, belonging to a technical committee, and eventually organizing symposia.

- Enhancing the interactions of our different core groups (industry, labs, academia, and students) is imperative. It is effortless for each of us to stay in our comfort zones with people we know, but we learn much more and make those insightful leaps in knowledge through interaction with others.

- Providing strong offerings to members both at the meetings and away is vital. Our society exists to serve the members. We can not be afraid to try new products while maintaining our strong core. These products might include technical workshops, more opportunities for students to interact with seasoned professionals, extended classes which serve as retraining tools for professionals, access to technical databases and libraries, and less technical and more hands-on presentations for practitioners to present their knowledge. We must also provide products for members who are unable to attend the meetings. If a new feature would make us more valuable to our members, then we should consider taking action.

I truly believe that TMS can help every member become a better-rounded professional, but we need to find more ways to reach out to our current members and those who do not currently participate. An individual gains the most by being actively involved in TMS. I would like to assist TMS to focus on its customers-the membership. We must make our professional society so appealing that people want to join and take an active role.

Finally, remember that what you get out of an organization is directly proportional to what you put in. Look for ways to be involved in the future and don't be afraid to say "Yes" when we ask for your participation in the future.

Ray Peterson is a Technology Director at Aleris International, Rockwood, Tennessee and the 2009 TMS President. 